\title{
FIELD EVALUATION OF CERTAIN INSECTICIDES AGAINST SOME INSECT PESTS INFESTING ORANGE TREES Ghanim, N.M. ${ }^{1}$ and Laila R. A. Elgohary ${ }^{2}$ \\ 1 Plant Protection Research Institute, Agricultural Research Center, Dokki, Giza, Egypt. \\ ${ }^{2}$ Pesticide Dept., Faculty of Agriculture, Mansoura University, Egypt.
}

\begin{abstract}
The present study aimed to evaluate the efficacy of Thiamethoxam, Imidacloprid, Spirotetramat, Sulfoxaflor, Buprofezin, Dimethoate, Phosmet and Mineral oil against Phyllocnistis citrella Stainton, Planococcus citri (Risso), Lepidosaphes beckii (Newman) and Ceroplastes floridensis Comstock infesting orange trees (Citrus sinensis L. (Rutacea)) under field conditions. The experiments were conducted in the Experimental Farm, Faculty of Agriculture, Mansoura University, Dakahlia Governorate, Egypt. The obtained results showed that the highest effective treatment on $P$. citrella was that of Thiamethoxam (the mean reduction percentages was $82.9 \%$ ) followed by Imidacloprid $(78.6 \%)$, Dimethoate $(76.6 \%)$ and Sulfoxaflor (76.2\%). Dimethoate ranked the highest treatment against $P$. citri followed by Imidacloprid and Thiamethoxam, where their general mean reductions reached $89.9,82.9$ and $82.3 \%$, respectively. With respect to $L$. beckii, Dimethoate ranked the highest treatment followed by Phosmet which recorded general mean reductions of 90.8 and $90.7 \%$, respectively. Also, Dimethoate was the highest insecticide against $C$. floridensis (the general mean reduction percentages was $90.2 \%$ ) followed by Thiamethoxam (86.9\%) and Imidacloprid (86.1\%).
\end{abstract}

\section{INTRODUCTION}

Egypt stands among the largest oranges producing countries in the world and occupies the third rank in production amongst the Mediterranean basin countries (FAO, 2011). Egyptian citrus has relative advantages in terms of yield and fruit quality, early ripening, relative low labor cost and nearness to international importing markets. It contains large amounts of phytochemicals which offer health benefits such as ascorbic acid and carbohydrates (Latif et al., 2013). Unfortunately, citrus trees are attacked by several insect pests among them the citrus leaf miner, Phyllocnistis citrella Stainton (Lepidoptera: Gracillariidae), the citrus mealybug, Planococcus citri (Risso) (Hemiptera: Pseudococcidae), the purple scale, Lepidosaphes beckii (Newman) (Hemiptera: Diaspididae) and the Florida wax scale, Ceroplastes floridensis Comstock (Homoptera: Coccidae).

Phyllocnistis citrella is an important pest of citrus orchards (Heppner, 1995). It occurs all the year round and attacks more than half of the new leaves produced on citrus trees (Wilson, 1991). Citrus nursery production systems are especially susceptible to $P$. citrella damage because seedlings and young trees flush nearly continuously and their ability to store nutrients is limited (Villanueva-Jimenez and Hoy, 1998). The damage is directly related to the ratio of the young leaves and the total canopy of the young trees (Argov and Rossler, 1998). Bautista-Martinez et al. (1998) suggest that P. citrella 
can augment the severity of citrus canker, Xanthomonas citri Dowson and other fungus pathogens such as Alternaria on damaged leaves.

The citrus mealybug, $P$. citri is one of the important pests attacking citrus plantations. Ahmed and Abd-Rabou (2010) reported that it found to infest 65 plant species belonging to 36 families in Egypt.

The purple scale $L$. beckii is a polyphagous species that has been recorded from hosts belonging to 45 genera in 11 plant families including citrus which attacks leaves, trunk and fruits (Davidson and Miller, 1990). It is a major destructive pest of citrus in Egypt and is widely distributed throughout the tropical and subtropical regions of the world (Danzig and Pellizzari, 1998).

C. floridensis is widely distributed in tropical and subtropical regions around the world (Ashmead, 1980). It attacks a great number of host plants especially Citrus spp. Its main damage is due to the copious production of honey dew (especially in the large populations) which serves as a substrate for various sooty mould fungi (Podoler et al., 1981).

Scale insects and mealybugs injure citrus trees by feeding on the plant sap through leaves, twigs and fruits causing defoliation and drying up of young twigs, so affecting the commercial value of fruits and their export potential. Therefore chemical control is necessary to keep the population of insect pests below economic threshold level.

Systemic insecticides are being developed and used for insect control on the variety of crops around the world (Yue et al. 2003). Among these neonicotinoid groups, Imidacloprid has a broad spectrum activity and low mammalian toxicity; it has long a unique property of excellent translaminar activity (Chauhan et al. 2013). Also, Thiamethoxam, comes from a family of insecticides known as the second-generation neonicotinoids.

The present study aimed to compare the efficacy of the neonicotinoid (Thiamethoxam \& Imidacloprid) and other insecticides (i.e Spirotetramat, Sulfoxaflor, Buprofezin, Dimethoate, Phosmet \& Mineral oil) against $P$. citrella, P. citri, L. beckii and C. floridensis infesting orange trees.

\section{MATERIALS AND METHODS}

Experiments were conducted in The Experimental Farm, Faculty of Agriculture, Mansoura University, Dakahlia Governorate, Egypt to evaluate efficacy of certain insecticides (Table 1) against the insects under study of the lepidopterous pest, $P$. citrella (Family: Gracillariidae) in addition to the hemipterous pests, P. citri (Family: Pseudococcidae), L. beckii (Family: Diaspididae) and C. floridensis (Family: Coccidae) infesting orange trees (Citrus sinensis L. (Rutacea)) under field conditions.

The design of experiment was conducted in a Randomized Block Design. The selected orange trees (about of 20 years old) received all the recommended agricultural practices. The experimental area divided into nine treatments, eight of them treated with tested insecticides at the recommended rates, while the $9^{\text {th }}$ treatment served as a control. The tested compounds were applied on the $26^{\text {th }}$ of August, 2014 using motor sprayer of 600 liters in capacity. Treatments including the untreated (check) were 
replicated five times with sixteen trees per replicate making a total of 80 orange trees per treatment, approximately having similar size, shape, height, and vigor. The tested insecticides were applied as complete coverage.

One hundred leaves from each treatment (20 leaves/replicate) were collected immediately before spraying and after 1, 2, 3 and 4 weeks (for $P$. citrella) \& after 2, 4, 6 and 8 weeks (for L. beckii) of application. Fifty twigs (approximately $20 \mathrm{~cm}$ in length) from each treatment (10 twigs/replicate) were collected immediately before spraying and after 1, 2, 3 and 4 weeks (for $P$. citri) \& after 2, 4, 6 and 8 weeks (for $C$. floridensis) of application. The picked samples were put in marked cloth bags and transferred to the laboratory for counting insects using the stereoscopic binocular microscope. Reduction percentages in both population and infestation were estimated according to Henderson and Tilton's formula (1955). Data were analyzed using analysis of variance (ANOVA) followed by Least Significant Difference (LSD). Probability of 0.05 or less was considered significant. All statistical analysis was done with CoHort Software 2004.

Table1. The tested insecticides

\begin{tabular}{|l|c|c|c|}
\hline $\begin{array}{c}\text { Common } \\
\text { name }\end{array}$ & Trade name & Field recommended rate & Group \\
\hline Thiamethoxam & Actara 25\% WG & $25 \mathrm{gm} / 100 \mathrm{~L}$ & Neonicotinoid \\
\hline Imidacloprid & Chinook 35\% SC & $75 \mathrm{ml} / 100 \mathrm{~L}$ & Neonicotinoid \\
\hline Spirotetramat & Movento $10 \% \mathrm{SC}$ & $40 \mathrm{ml} / 100 \mathrm{~L}$ & Tetramic acid \\
\hline Sulfoxaflor & Transform $50 \%$ WG & $125 \mathrm{gm} / \mathrm{fed}$. & Sulfoximine \\
\hline Buprofezin & Applaud $25 \% \mathrm{SC}$ & $600 \mathrm{ml} / \mathrm{fed}$. & $\begin{array}{c}\text { Chitin synthesis } \\
\text { inhibitors }\end{array}$ \\
\hline Dimethoate & Dancothoate $40 \% \mathrm{EC}$ & $150 \mathrm{ml} / 100 \mathrm{~L}$ & Organophosphate \\
\hline Phosmet & Imidan $50 \% \mathrm{WP}$ & $140 \mathrm{gm} / 100 \mathrm{~L}$ & Organophosphate \\
\hline Mineral oil & Tiger $97 \% \mathrm{EC}$ & $1.5 \mathrm{~L} / 100 \mathrm{~L}$ & $\begin{array}{c}\text { lubrication fraction of } \\
\text { petroleum oil }\end{array}$ \\
\hline
\end{tabular}

\section{RESULTS}

\section{The citrus leaf miner, $P$. citrella:}

After one week of application, Thiamethoxam exhibited the highest reduction percentage of $P$. citrella population $(67.1 \%)$; while, Dimethoate was the worst recording the lowest reduction percentage of $52.7 \%$. After two weeks of treatment, both Imidacloprid and Dimethoate as well as Thiamethoxam exhibited relatively high reduction percentages in $P$. citrella population and then their effects increased gradually till the fourth week of treatment (Table, 2).

The highest effective treatment on $P$. citrella population was that of Thiamethoxam (the mean reduction percentage was $82.9 \%$ ). While, Imidacloprid treatment ranked the second effective treatment (the mean reduction percentage was $78.6 \%$ ) followed by Dimethoate $(76.6 \%)$ and Sulfoxaflor $(76.2 \%)$. Buprofezin was the lowest effective compound on $P$. citrella population (the mean reduction percentage was $72.1 \%$ ) (Table, 2). 
Table (2). Effect of certain insecticides against the citrus leaf miner, Phyllocnistis citrella Stainton (Lepidoptera: Gracillariidae) on orange trees.

\begin{tabular}{|c|c|c|c|c|c|c|c|c|c|c|c|}
\hline \multirow{3}{*}{ Treatment } & \multirow{3}{*}{$\begin{array}{l}\text { Pre- } \\
\text { spray }\end{array}$} & \multicolumn{10}{|c|}{ Mean number and \% reduction after treatment (in weeks) } \\
\hline & & \multicolumn{2}{|l|}{1} & \multicolumn{2}{|l|}{2} & \multicolumn{2}{|c|}{3} & \multicolumn{2}{|c|}{4} & \multicolumn{2}{|c|}{ Mean } \\
\hline & & No. & $\mathbf{R} \%$ & No. & $\mathbf{R} \%$ & No. & $\mathbf{R} \%$ & No. & $\mathbf{R} \%$ & No. & $\mathbf{R} \%$ \\
\hline Thiam & $9.8 \pm 2.5$ & $4.0 \pm 1.0$ & 67.1 & $2.2 \pm 0.8$ & 81.2 & $1.0 \pm 0.7$ & 91.8 & $1.2 \pm 0.8$ & 90.8 & 2.1 & 82.9 \\
\hline Imidac & $11.6 \pm 4.7$ & $5.8 \pm 0.8$ & 59.6 & $3.0 \pm 0.7$ & 78.4 & $1.6 \pm 0.5$ & 88.9 & $2.0 \pm 0.7$ & 87.0 & 3.1 & 78.6 \\
\hline Spirote & $9.4 \pm 2.7$ & $4.8 \pm 2.2$ & 58.8 & $3.2 \pm 1.3$ & 71.5 & $1.8 \pm 1.5$ & 84.5 & $2.2 \pm 0.8$ & 82.4 & 3.0 & 74.5 \\
\hline Sulfoxaflor & $10.4 \pm 3.2$ & $5.2 \pm 2.5$ & 59.6 & $3.2 \pm 1.3$ & 74.3 & $1.8 \pm 0.8$ & 86.0 & $2.2 \pm 0.8$ & 84.0 & 3.1 & 76.2 \\
\hline Buprofezin & $8.6 \pm 4.8$ & $5.0 \pm 1.6$ & 62.1 & $3.4 \pm 0.5$ & 66.9 & $2.2 \pm 0.8$ & 79.4 & $2.3 \pm 0.8$ & 79.8 & 3.2 & 72.1 \\
\hline Dimethoate & $11.6 \pm 4.0$ & $6.8 \pm 1.6$ & 52.7 & $3.2 \pm 0.8$ & 76.9 & $1.4 \pm 0.5$ & 90.3 & $2.0 \pm 0.7$ & 87.0 & 3.4 & 76.6 \\
\hline Phosmet & $10.2 \pm 2.2$ & $5.8 \pm 3.8$ & 54.1 & $3.6 \pm 1.5$ & 70.5 & $1.2 \pm 0.8$ & 90.5 & $1.8 \pm 0.8$ & 86.7 & 3.1 & 75.7 \\
\hline Minera & $10.2 \pm 3.3$ & $5.6 \pm 2.1$ & 55.7 & $3.6 \pm 1.3$ & 70.5 & $1.8 \pm 0.8$ & 85.8 & $2.0 \pm 0.7$ & 85.2 & 3.3 & 74.1 \\
\hline Contr & $9.2 \pm 3.3$ & $11.4 \pm 2.1$ & ---- & $11.0 \pm 1.2$ & ---- & $11.4 \pm 1.3$ & ---- & $12.2 \pm 1.5$ & ---- & 11.5 & ---- \\
\hline L.S.D. $P=5 \%$ & 4.5 & 2.7 & ---- & 1.4 & --- & 1.2 & ---- & 1.1 & ---- & --- & --- \\
\hline
\end{tabular}

Note: No. $=$ Number of insect $/ 20$ leaves and $\mathbf{R} \%=$ Reduction percentage.

\section{The citrus mealybug, $P$. citri:}

As shown in Table (3), Dimethoate exhibited the highest reduction percentage after one week of application. On contrary, Mineral oil and Spirotetramat were the lowest effective insecticides after one week. But, after two weeks, Mineral oil exhibited relatively high reduction percentage in $P$. citri population and its effects gradually increased till the fourth week of treatment (Table, 3).

In general, Dimethoate showed the highest value of \% reduction of $P$. citri followed by Imidacloprid and Thiamethoxam where their general mean reductions were $89.9,82.9$ and $82.3 \%$, respectively. The other tested insecticides exhibited general mean reductions between 78.2 and $79.8 \%$.

Table (3). Effect of certain insecticides against the citrus mealybug, Planococcus citri (Risso) (Hemiptera: Pseudococcidae) on orange trees.

\begin{tabular}{|c|c|c|c|c|c|c|c|c|c|c|c|}
\hline \multirow{3}{*}{ Treatment } & \multirow{3}{*}{$\begin{array}{c}\text { Pre- } \\
\text { spray }\end{array}$} & \multicolumn{10}{|c|}{ Mean number and \% reduction after treatment (in weeks) } \\
\hline & & \multicolumn{2}{|c|}{1} & \multicolumn{2}{|c|}{2} & \multicolumn{2}{|c|}{3} & \multirow[b]{2}{*}{ No. } & \multirow[b]{2}{*}{$\mathbf{R} \%$} & \multicolumn{2}{|c|}{ Mean } \\
\hline & & No. & $\mathbf{R} \%$ & No. & $\mathbf{R} \%$ & No. & $\mathbf{R} \%$ & & & No. & $\mathbf{R} \%$ \\
\hline Thiamethoxam & $6.8 \pm 1.1$ & $2.2 \pm 0.8$ & 68.8 & $1.8 \pm 0.8$ & 80.1 & $1.0 \pm 0.8$ & 86.8 & $0.4 \pm 0.8$ & 93.6 & 1.6 & 82.3 \\
\hline Imidacloprid & $6.0 \pm 1.0$ & $2.0 \pm 0.7$ & 67.9 & $1.6 \pm 0.5$ & 80.0 & $0.6 \pm 0.5$ & 91.0 & $0.4 \pm 0.5$ & 92.8 & 1.4 & 82.9 \\
\hline Spirotetramat & $6.6 \pm 1.5$ & $3.0 \pm 1.0$ & 56.2 & $2.2 \pm 1.1$ & 75.0 & $0.6 \pm 0.8$ & 91.8 & $0.6 \pm 0.8$ & 90.2 & 1.6 & 78.2 \\
\hline Sulfoxaflor & $5.4 \pm 1.5$ & $2.0 \pm 1.0$ & 64.3 & $1.6 \pm 1.3$ & 77.8 & $0.8 \pm 0.8$ & 86.7 & $0.6 \pm 0.5$ & 88.8 & 1.3 & 78.3 \\
\hline Buprofezin & $5.8 \pm 0.8$ & $2.0 \pm 0.7$ & 66.7 & $2.0 \pm 1.0$ & 74.1 & $0.8 \pm 0.4$ & 87.6 & $0.4 \pm 0.5$ & 92.6 & 1.3 & 79.8 \\
\hline Dimethoate & $8.0 \pm 0.7$ & $1.8 \pm 0.7$ & 78.3 & $1.0 \pm 0.7$ & 90.6 & $0.6 \pm 0.5$ & 93.2 & $0.2 \pm 0.4$ & 97.3 & 0.9 & 89.9 \\
\hline Phosmet & $6.2 \pm 1.3$ & $2.2 \pm 0.8$ & 65.8 & $2.0 \pm 1.0$ & 75.8 & $0.8 \pm 0.8$ & 88.4 & $0.6 \pm 0.8$ & 89.5 & 1.4 & 79.7 \\
\hline Mineral oil & $4.4 \pm 0.5$ & $2.1 \pm 0.5$ & 54.0 & $1.0 \pm 0.7$ & 83.0 & $0.6 \pm 0.5$ & 87.7 & $0.4 \pm 0.5$ & 90.2 & 0.8 & 78.7 \\
\hline Control & $5.4 \pm 1.3$ & $5.6 \pm 1.5$ & \begin{tabular}{|l|}
--- \\
\end{tabular} & $7.2 \pm 1.8$ & \begin{tabular}{|l|}
---- \\
\end{tabular} & $6.0 \pm 1.2$ & ---- & $5.0 \pm 1.0$ & ---- & 6.0 & ---- \\
\hline L.S.D.P $=5 \%$ & 1.5 & 1.1 & ---- & 1.3 & |--- & 1.0 & ---- & \begin{tabular}{|l|}
0.9 \\
\end{tabular} & ---- & --- & ---- \\
\hline
\end{tabular}

\section{The purple scale insect, $L$. beckii:}

After two weeks of treatment, Dimethoate and Phosmet exhibited the highest reduction percentages; while, Mineral oil exhibited the lowest one. After eight weeks, Phosmet ranked the highest insecticide against $L$. beckii 
population followed by Mineral oil (reduction percentages were 94.4 and 91.1\%) (Table, 4).

The obtained results showed that both Dimethoate and Phosmet recorded the highest values of general mean of \% reduction in L. beckii population of 90.8 and $90.7 \%$, respectively. The other tested treatments exhibited general mean reductions between 82.5 and $88.7 \%$ (Table, 4).

Table (4). Effect of certain insecticides against the purple scale, Lepidosaphes beckii (Newman) (Homoptera: Diaspididae) on orange trees.

\begin{tabular}{|c|c|c|c|c|c|c|c|c|c|c|c|}
\hline \multirow{3}{*}{ Treatment } & \multirow{3}{*}{$\begin{array}{l}\text { Pre- } \\
\text { spray }\end{array}$} & \multicolumn{10}{|c|}{ Mean number and \% reduction after treatment (in weeks) } \\
\hline & & \multicolumn{2}{|c|}{2} & \multicolumn{2}{|c|}{4} & \multicolumn{2}{|c|}{6} & \multicolumn{2}{|c|}{8} & \multicolumn{2}{|c|}{ Mean } \\
\hline & & No. & $\mathbf{R} \%$ & No. & $\mathbf{R} \%$ & No. & $\mathbf{R} \%$ & No. & $\mathbf{R} \%$ & No. & $\mathbf{R} \%$ \\
\hline Thiamethoxam & $16.0 \pm 4.5$ & $4.2 \pm 0.8$ & 79.3 & $2.6 \pm 0.5$ & 89.0 & $1.4 \pm 0.5$ & 94.5 & $2.6 \pm 0.9$ & 90.2 & 2.7 & 88.7 \\
\hline Imidac & $13.0 \pm 3$ & $42+13$ & 74.6 & $2.8 \pm 1.1$ & 85.4 & $1.8 \pm 0.8$ & 91.4 & $2.8 \pm 0.8$ & 87.0 & 2.9 & 85.1 \\
\hline Spirotetramat & $16.0 \pm 4$ & 1 & 78.3 & $3.2 \pm($ & 86.5 & $2.2 \pm 0.8$ & 91.4 & $2.8 \pm 0.8$ & 89.4 & 3.2 & 86.7 \\
\hline Sulfoxaflor & $14.6 \pm 4.2$ & $.0 \pm 1.2$ & 78.4 & $2.6 \pm$ & 87.9 & $1.8 \pm 0$ & 92.3 & $2.4 \pm 0.5$ & 90.0 & 2.7 & 87.7 \\
\hline Buprofezin & $14.2 \pm 2.9$ & $4.2 \pm 0.8$ & 76.7 & $2.8 \pm 1$ & 86.6 & $1.6 \pm 0.9$ & 93.0 & $2.6 \pm 0.9$ & 88.9 & 2.8 & 86.9 \\
\hline Dimethoate & $16.0 \pm 4.3$ & $2.8 \pm 0.8$ & 86.2 & $2.2 \pm 0.8$ & 90.7 & $1.4 \pm 0.5$ & 94.5 & $2.4 \pm 0.5$ & 90.9 & 2.2 & 90.8 \\
\hline Phosmet & $17.2 \pm 2.3$ & $3.6 \pm 0.9$ & 83.5 & $2.4 \pm 1.1$ & 90.5 & $1.8 \pm 0.8$ & 93.5 & $1.6 \pm 0.6$ & 94.4 & 2.4 & 90.7 \\
\hline Mineral oil & $12.2 \pm 1.8$ & $4.8 \pm 0.8$ & 69.0 & $3.6 \pm 0.5$ & 80.0 & $2.4 \pm 1.1$ & 87.7 & $1.8 \pm 0.6$ & 91.1 & 3.2 & 82.5 \\
\hline Control & $12.6 \pm 1$. & $16.0 \pm 2.7$ & --- & $18.6 \pm 2.4$ & $-\cdots$ & $20.2 \pm 1.9$ & --- & $20.8 \pm 2.2$ & --- & 18.9 & --- \\
\hline L.S.D. $P=5 \%$ & 4.4 & 1.7 & ---- & 1.5 & ---- & 1.3 & \begin{tabular}{|l|}
---- \\
\end{tabular} & 1.3 & ---- & ---- & $-\ldots$ \\
\hline
\end{tabular}

Note: No. $=$ Number of insect $/ 20$ leaves and $R \%=$ Reduction percentage.

Table (5). Effect of certain insecticides against the Florida wax scale, Ceroplastes floridensis Comstock (Homoptera: Coccidae) on orange trees.

\begin{tabular}{|c|c|c|c|c|c|c|c|c|c|c|c|}
\hline \multirow{3}{*}{ Treatment } & \multirow{3}{*}{$\begin{array}{l}\text { Pre- } \\
\text { spray }\end{array}$} & \multicolumn{10}{|c|}{ Mean number and $\%$ reduction after treatment (in weeks) } \\
\hline & & \multicolumn{2}{|c|}{2} & \multicolumn{2}{|c|}{4} & \multicolumn{2}{|c|}{6} & \multicolumn{2}{|c|}{8} & \multicolumn{2}{|c|}{ Mean } \\
\hline & & No. & $\mathbf{R} \%$ & No. & $\mathbf{R} \%$ & No. & $\mathbf{R} \%$ & No. & $\mathbf{R} \%$ & No. & $\mathbf{R} \%$ \\
\hline Thiamethoxam & $8.0 \pm 1.0$ & $2.2 \pm 0.8$ & 73.2 & $1.2 \pm 0.8$ & 85.0 & $0.6 \pm 0.9$ & 93.2 & $0.2 \pm 0.4$ & 97.7 & 1.1 & 86.9 \\
\hline Imidacloprid & $8.2 \pm 2$ & $2.2 \pm 0.8$ & 73.9 & $1.4 \pm 0.5$ & 82.9 & $0.8 \pm 0.8$ & 91.2 & $0.4 \pm 0.5$ & 95.5 & 1.2 & 86.1 \\
\hline Spirotetramat & $7.0 \pm 2.1$ & $3.2 \pm$ & 55.5 & $1.2 \pm$ & 82.9 & $0.8 \pm$ & 89.7 & $0.6 \pm 0$ & 92.1 & 1.5 & 79.6 \\
\hline Sulfox & $7.6 \pm 1.5$ & $3.0 \pm$ & 61.5 & $1.6 \pm 0.5$ & 78.9 & $0.8 \pm 0.8$ & 90.5 & $0.8 \pm 0.8$ & 90.2 & 1.6 & 80.0 \\
\hline Buprofezin & $7.2 \pm 2.2$ & $2.4 \pm 1.1$ & 67.5 & $1.2 \pm 1.3$ & 83.3 & $0.6 \pm 0.5$ & 92.5 & $0.4 \pm 0.5$ & 94.9 & 1.2 & 84.2 \\
\hline Dimethoate & $7.8 \pm 1.8$ & $2.0 \pm 0.7$ & 75.0 & $0.8 \pm 0.8$ & 89.7 & $0.2 \pm 0.4$ & 97.7 & $0.2 \pm 0.4$ & 97.6 & 0.8 & 90.2 \\
\hline Phosmet & $8.8 \pm 1.6$ & $2.6 \pm 1.1$ & 71.2 & $1.6 \pm 1.1$ & 81.8 & $0.8 \pm 0.8$ & 91.8 & $0.6 \pm 0.9$ & 93.7 & 1.4 & 84.9 \\
\hline Mine & $7.0 \pm 1.2$ & $3.0 \pm 0.7$ & 58.2 & $1.6 \pm 0.5$ & 77.1 & $0.4 \pm 0.9$ & 94.8 & $0.4 \pm 0.9$ & 94.7 & 1.4 & 81.0 \\
\hline Control & $7.6 \pm 1.1$ & $7.8 \pm 1.6$ & ---- & $7.6 \pm 2.5$ & --- & $8.4 \pm 1.5$ & ---- & $8.2 \pm 1.3$ & ---- & 8.0 & --- \\
\hline L.S.D.P $=5 \%$ & 2.3 & 1.3 & ---- & 1.5 & ---- & 1.1 & \begin{tabular}{|l|}
--- \\
\end{tabular} & 1.0 & ---- & ---- & $\begin{array}{ll}--- \\
\end{array}$ \\
\hline
\end{tabular}

Note: No. = Number of insect $/ 10$ twigs and $R \%=$ Reduction percentage.

\section{The Florida wax scale, $C$. floridensis:}

Dimethoate, Imidacloprid and Thiamethoxam were the most effective insecticides after two weeks of treatment. While, Mineral oil and Spirotetramat were the lowest treatments after the same period. After eight weeks of treatment, Thiamethoxam and Dimethoate were the most effective treatments against $C$. floridensis population (Table, 5). 
Data illustrated in Table (5) indicate that Dimethoate was the best compound against $C$. floridensis recording general mean reduction percentage of $90.2 \%$ followed by Thiamethoxam (86.9\%) and Imidacloprid (86.1\%). While, Spirotetramat showed the lowest general mean reduction percentage $(79.6 \%)$.

\section{Discussion}

The present study was conducted to evaluate the efficacy of Thiamethoxam, Imidacloprid, Spirotetramat, Sulfoxaflor, Buprofezin, Dimethoate, Phosmet and Mineral oil against some pests (P. citrella, P. citri, $L$. beckii and $C$. floridensis) infesting orange trees under field conditions.

The obtained data showed that Thiamethoxam and Imidacloprid were the most effective treatments in controlling $P$. citrella. These results are in agreements with Raga et al. (2001) and Latif et al. (2013). They reported that Thiamethoxam and Imidacloprid significantly reduced the $P$. citrella population on citrus leaves. Salas et al. (2006) also conducted experiment to control $P$. citrella in nursery lemon plants with systemic insecticides. They concluded that $P$. citrella control with systemic insecticides such as Imidacloprid and Thiamethoxam was possible because they gave good control.

After one week of treatment, Thiamethoxam exhibited high reduction percentage of $P$. citrella population. Also, Latif et al. (2013) stated that Thiamethoxam showed a significant reduction of $P$. citrella larvae after five days of application.

With respect to the citrus mealybug, $P$. citri, all used insecticides had negative effect on its population. Dimethoate, Imidacloprid and Thiamethoxam were the highest effective insecticides against this pest; while, Spirotetramat recorded a relatively low effects against $P$. citri. According to Willmott (2012), Thiamethoxam, a neonicotinoid-based insecticide, provided the highest $P$. citri mortality. Also, Castle and Prabhaker (2011) reported that there was a significant difference between water control and both Thiamethoxam and Imidacloprid treatments against pink hibiscus mealybug, Maconellicoccus hirstus (Green). Moreover, the same authors reported no significant differences between Thiamethoxam and Imidacloprid. On another hand, Kahramanoglu and Usanmaz (2013) reported that the organophosphorus, Chlorpyrifos-ethyl is commonly used for control of $P$. citri also, added that Spirotetramat had a significant effect on $P$. citri population. While, Satar et al. (2013) recorded that Spirotetramat have lesser effect on $P$. citri than Imidacloprid, Chlorpyrifos-ethyhl, Buprofezin and summer oil. Also, they added that all of these treatments have significant effects on P. citri.

The highest effect of Imidacloprid and Thiamethoxam had been recorded after 3-4 weeks of treatment. Also, previous results reported that the highest effects of neonicotinoid-based insecticides on mealybugs were recorded after 3 weeks (Willmott, 2012) and 4 weeks of treatment (Castle and Prabhaker, 2011). Despite this, in these studies, the treatments took 3-4 weeks before the highest mortality was observed, which suggest that factors such as water solubility and plant growth rate may affect translocation, thus 
influencing the efficacy of systemic insecticides. For instance, the water solubility of Imidacloprid is $0.6 \mathrm{~g} / \mathrm{L}$ at $20^{\circ} \mathrm{C}$ whereas the water solubility of Thiamethoxam is $4.1 \mathrm{~g} / \mathrm{L}$ at $20^{\circ} \mathrm{C}$ (Jeschke et al., 2011). Therefore, Thiamethoxam may have been absorbed and translocated throughout the plants more rapidly than Imidacloprid.

The highest effective treatments on scale insects $(L$. beckii and $C$. floridensis) were those of Dimethoate, Phosmet, Thiamethoxam and Imidacloprid, respectively. These results come in agreement with those obtained by Helmy and Tawfik (1989); found that organophosphorus insecticides had high effects against $L$. beckii on orange trees. Also, Leibee and Savage (1994) mentioned that Dimethoate was the highest effective treatment against the diaspidid, Pseudaulacaspis cockerelli (Cooley). Dewer et al. (2012) stated that using of IGRs reduced the target pests, L. beckii and California red scale, Aonidiella aurantii Maskell. According to Hassan and Radwan (2014), the effect of the organophosphorus, Chlorpyrifos methyl was more effective in controlling the black parlatoria, Parlatoria ziziphi (Lucas) in comparison with Imidacloprid and Thiamethoxam. Also they added that the effect of insecticides on the total populations showed gradual decrease in density by the time elapsed from spraying. These results come with same line of the present results.

Some of the newer insecticides, such as Thiamethoxam, Imidacloprid Spinosad, Indoxacarb and Emamectin benzoate, have been shown to be relatively safe on predacious hemipterans, mites, coccinellids, lacewings and some parasitoids (Elzen, 2001). So, by using Thiamethoxam and Imidacloprid which give high reduction percentages in $P$. citrella, $P$. citri, $L$. beckii and $C$. floridensis populations not only protects our natural enemies but also our environment.

\section{REFERENCES}

Ahmed, N.H. and S.M. Abd-Rabou (2010). Host plants, geographical distribution, natural enemies and biological studies of the citrus mealybug, Planococcus citri (Risso) (Hemiptera: Pseudococcidae). Egypt. Acad. J. Biolog. Sci., 3(1):39-47.

Argov, Y. and Y. Rossler (1998). Rearing methods for the citrus leafminer Phyllocnistis citrella Stainton and its parasitoids in Israel. Biological control, 11: 18-21.

Ashmead, A.H. (1980). The white scale of the orange. Can. Ent., 12: 252264.

Bautista-Martinez, N.; J.L. Carrillo-Sanchez; H. Bravo-Mojica and S.D. Koch (1998). Natural parasitism of Phyllocnistis citrella (Lepidoptera: Gracillariidae) at Cuitlahuac, Veracruz, Mexico. Florida Ent., 8(1): 3073.

Castle, S.J., and N. Prabhaker (2011). Field evaluations of two systemic neonicotinoid insecticides against pink hibiscus mealybug (Maconellicoccus hirstus (Green) on mulberry trees. J. Pesticide Science, 84: 363-371. 
Chauhan, S.S., S. Agrawal and A. Srivastava (2013). Effect of imidacloprid insecticide residue on biochemical parameters in potatoes and its estimation by HPLC. Asian J. Pharm. Clin. Res., I 6(3): 114-117.

Cohort Software (2004). CoStat. www.cohort.com Montery, California, USA.

Danzig, E.M. and G. Pellizzari (1998). Catalogue of Palaearctic Coccoidea. Hungarian Academy of Sciences. Akaprint, Nyomdaipari Kft., Budapest, Hungary, 172-370.

Davidson, J.A. and D.R. Miller (1990). Armored scale insects their biology, natural enemies and control. 4B Elsevier/Netherlands, pp. 603-632.

Dewer, Y., S. Abdel-Razak and A. Barakat (2012). Comparative efficacy of some insecticides against purple scale insect, Lepidosaphes beckii (Hemiptera: Coccoidea) and its parasitoid in citrus orchard in Egypt. Egypt. Acad. J. Biolog. Sci., 5(3): $121-127$.

Elzen, G.W. (2001). Lethal and sublethal effects of insecticide residues on Orius insidiosus (Hemiptera: Anthocoridae) and Geocoris punctipes (Hemiptera: Lygaeidae). Econ. J. Entomol., 94: 55-59.

FAO (2011): http://faostat.fao.org/site/339/default.aspx Food and Agricultural commodities production.

Hassan, N.A. and S.G. Radwan (2014). Safety and proper use of pesticides on orange fruits. Egypt. Acad. J. Biolog. Sci., 6(1): 1-9.

Helmy, E.I. and M.H. Tawfik (1989). Effectiveness of summer spraying on the scale insect Lepidosaphes beckii (Newm.) and its parasitoid Aphytis lepidosaphes Comp. Zagazig J. Agric. Res., 16(3): 349-353.

Henderson C.F. and F.W. Tilton (1955). Tests with acaricides against the brown wheat mite. J. Econ. Ent., 48: 157-161.

Heppner, J. B. (1995). Citrus leafminer (Lepidoptera: Gracillariidae) on fruit in Folida. Florida Ent., 78: 183-186.

Jeschke, P., R. Nauen, M. Schindler and A. Elbert (2011). Overview of the status and global strategy for neonicotinoids. J. Agriculture Food Chemistry, 59: 2897-2908.

Kahramanoglu, I. and S. Usanmaz (2013). Management strategies of fruit damaging pests of pomegranates: Planococcus citri, Ceratitis capitata and Deudorix (Virachola) livia. Afr. J. Agric. Res., 8(49): 6563-6568.

Latif, I., S. Ahmad, M.A. Qayyoum and B.S. Khan (2013). Evaluation of infestation of Phyllocnistis citrella Stainton (Lepidoptera: Gracillariidae) and its parasitism after the application of betacyhalothrin and thiamethoxam on quadrates of citrus trees. American-Eurasian J. Agric. \& Environ. Sci., 13 (7): 996-1003.

Leibee G.L. and K.E. Savage (1994). Insecticidal control of magnolia white scale (False oleander scale) (Homoptera: Diaspididae) on magnolia. Proc. Fla.State Hort. Soc., 107: 226-228.

Podoler, H., Y. Dreishpoun and D. Rosen (1981). Population dynamics of the Florida wax scale, Ceroplastes floridensis (Homoptera: Coccidae) on citrus in Israel. 1. A partial life table. Acta Oecologica / Oecologia Applicata, 2 (1): 81-91.

Raga, A., M.E. Satol, M.F. Souza and R.C. Siloto (2001). Comparison of spray insecticides against citrus leaf-miner. Arq. Inst. Biol., 68: 77-82. 
Salas, H.; L. Goane; A. Casmuz and Y. S. Zapatiel (2006). Control of citrus leafminer Phyllocnistis citrella Stainton in nursery lemon plants with systemic insecticides. Rev. Ind. Agríc. Tucuman (online). 83(2): 4952.

Satar, G., H.F. Ateş and S. Satar (2013). Effects of different insecticides on life stages of Planococcus citri Risso (Hemiptera: Pseudococcidae). IOBC WPRS Integrated Control in Citrus Fruit Crops Adana, Turkey 7-9 May.

Villanueva-Jimenez, J.A. and M.A. Hoy (1998). Critical points for attack-what do we know about the biology of the citrus leafminer? In M. A. Hoy (ed.), Managing the citrus leafminer, Proc. Intern. Conf., Orlando, Florida, April 23-25, 1996, 53-59. Gainesvill: Univ. Florida. 119 pp.

Willmott, A.L. (2012). Efficacy of systemic insecticides against the citrus mealybug, Planococcus citri, and pesticide mixtures against the western flower thrips, Frankliniella occidentalis, in protected environments. M. Sc., Fac. Agric., Kansas State University.

Wilson, C.G. (1991). Notes on Phyllocnistis citrella Stainton (Lepidoptera: Phyllocnistidae) attacking four citrus varieties in Darwin, Australia. J. Aust. Ent. Soc., 30: 77-78.

Yue, B., G.E. Wilde and F. Arthur (2003). Evaluation of Thiamethoxam and Imidacloprid as seed treatments to control European corn borer and Indian meal moth (Lepidoptera: Pyralidae) larvae. J. Econ. Entomol., 96(2): 503-509.

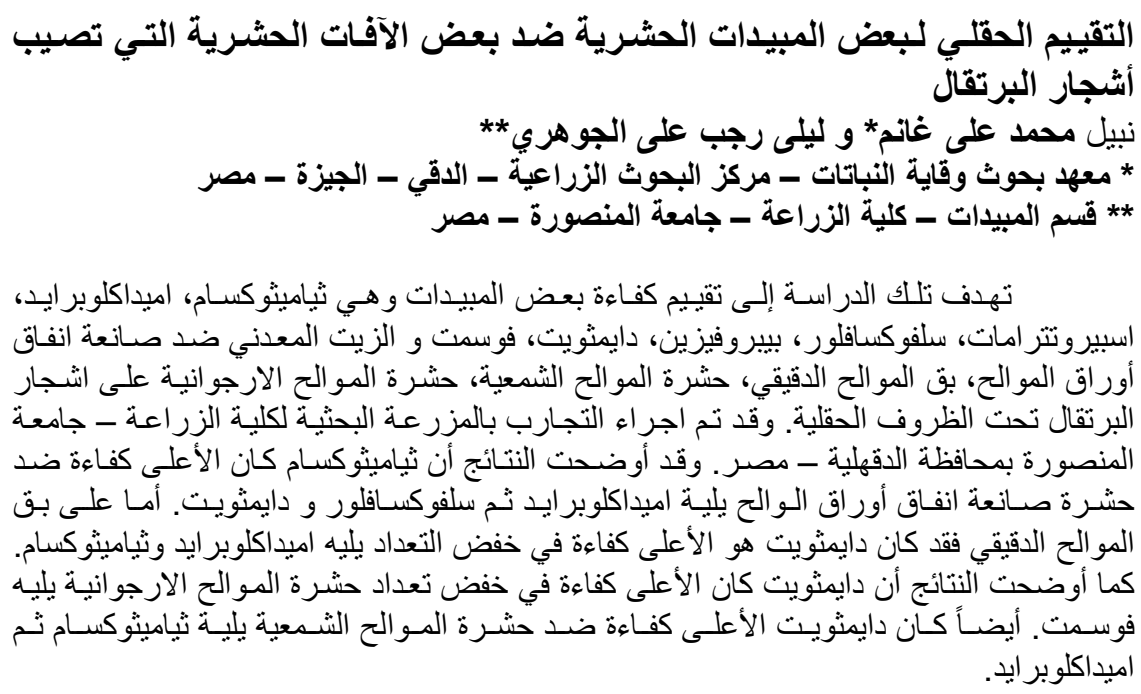

